PRIMER NOTE

\title{
Development of microsatellite markers for Carapa guianensis (Aublet), a tree species from the Amazon forest
}

\author{
C. C. VINSON,*V. C. R. AZEVEDO,+ I. SAMPAIO, ${ }^{*}$ and A. Y. CIAMPI† \\ *Universidade Federal do Pará, Campus de Bragança, Alameda Leandro Ribeiro, Aldeia, Bragança - Pará, CEP 68600-000, Brazil, \\ †Embrapa Recursos Genéticos e Biotecnologia, PqEB W5 Norte Final, Brazilia, DF, CEP 70770 900, PoBox 02372, Brazil
}

\begin{abstract}
Carapa guianensis is a timber species found in Central America and the north of South America. We have developed microsatellite primers which will allow analysis of gene flow and population genetic structure in natural populations of this tree species. Polymorphism of five microsatellite loci was evaluated using a total of $\mathbf{1 2}$ adult trees from a natural population. An average of 4.2 alleles per locus was detected, and expected heterozygosity ranging from 0.397 to 0.806 . These loci are being used for genetic population analysis in a managed forest in the state of Pará, in Amazonian Brazil, as part of the Dendrogene project.
\end{abstract}

Keywords: Amazon, Carapa guianensis, microsatellites, tropical tree

Received 2 July 2004; revision accepted 2 September 2004

Carapa guianensis Aublet. (Meliaceae), known locally as andiroba, is a climax species, with a monoecious sexual system. Andiroba reaches up to 30 meters and is an important timber species while its seeds are used for the extraction of an oil which has medicinal properties.

The Dendrogene project aims to apply scientific knowledge (species composition, reproductive health and genetic diversity of populations) to promote sustainable rainforest management in the Brazilian Amazon (Kanashiro et al. 2001). One important component of this work is the study of spatial genetic structure and gene flow in natural and logged populations. Microsatellite markers are increasingly being used as an effective tool for understanding population genetic structure. Dayanandan et al. (1999) developed and characterized three polymorphic microsatellite markers for C. guianensis, although gene flow and parentage studies require more loci. This paper describes the development of five microsatellite markers for C. guianensis.

DNA was extracted from expanded leaves of a single individual of Carapa guianensis, according to the CTAB protocol (Ferreira \& Grattapaglia 1995). Total DNA was digested with Tsp 509 I and separated on a 2\% agarose gel. The fragments of 300-800 bp were recovered with purification of the gel using the Qiaquick Gel Extraction kit of QIAGEN. All fragments were then used to construct a

Correspondence: C. C. Vinson. Fax: (55) (91) 425-1209; E-mail: ccvinson@yahoo.com.br microsatellite library as described by Rafalski et al. (1996). The DNA fragments were ligated to adaptors, hybridized to biotinylated (AG) 13 and (TC) ${ }_{13}$ and the oligo fragments separated using streptavidin magnetic beads. Selected fragments were ligated into a pGEMT-T Easy Vector (Promega, Madison, WI, USA) and transformed in competent $E$. coli XL1-Blue cells (Sambrook et al. 1989) which were grown overnight on $1 \times$ Luria-Bertani (LB) agar plates containing ampicilin, Xgal and IPTG. No selection with hybridization with a poly AG/TC probe were used. Polymerase chain reaction (PCR) amplification using M13 forward (-20) and M13 reverse was performed directly from the bacterial clones diluted in water, following the PCR protocol of Invitrogen. PCR products were purified using potassium acetate and ethanol. Sequencing reaction was performed with the M13 forward (-20) primer using the Amershan protocol. Products were detected with an ABI 377 (Applied Biosystems). We sequenced 189 clones that revealed 19 clones containing both microsatellites and appropriate flanking regions for primer design. For all of these clones we designed primers using the PRIMER 3 Output program (Rozen \& Skaletsky 2000).

Nineteen primers were synthesized and microsatellite loci amplified using PCR in $13 \mu \mathrm{L}$ containing: DNA (3 ng), PCR reaction buffer (10 mм Tris- $\mathrm{HCl}, \mathrm{pH} 8.3,50 \mathrm{~mm} \mathrm{KCl}$, $\left.1.5 \mathrm{mM} \mathrm{MgCl}_{2}\right)(1 \times)$, primer forward and reverse $(0.28 \mu \mathrm{M}$ each), $\mathrm{MgCl}_{2}$ (1.5 mM), BSA (Bovine Serum Albumin, Biolabs New England) (0.25 mg/mL), dNTP (0.25 mM) and Taq 
Table 1 Information of the five microsatellite marker loci of Carapa guianensis. Annealing temperature $\left(T_{\mathrm{a}}\right)$, number of individuals $(\mathrm{N})$, total number of alleles $(\mathrm{A})$, observed heterozygosity $\left(H_{\mathrm{O}}\right)$, expected heterozygosity $\left(H_{\mathrm{E}}\right)$ and first and second exclusionary power $\left[\operatorname{Pr}\left(\operatorname{Ex}_{1}\right)\right.$ and $\left.\operatorname{Pr}\left(\operatorname{Ex}_{2}\right)\right]$

\begin{tabular}{|c|c|c|c|c|c|c|c|c|c|c|c|}
\hline Locus & Array & Primer sequences $\left(5^{\prime}-3^{\prime}\right)$ & $\begin{array}{l}\text { Allele size } \\
\text { range bp }\end{array}$ & $\begin{array}{l}T_{\mathrm{a}} \\
\left({ }^{\circ} \mathrm{C}\right)\end{array}$ & $\mathrm{N}$ & A & $H_{\mathrm{O}}$ & $H_{\mathrm{E}}$ & $\operatorname{Pr}\left(\mathrm{Ex}_{1}\right)$ & $\operatorname{Pr}\left(\operatorname{Ex}_{2}\right)$ & $\begin{array}{l}\text { Accession } \\
\text { No. }\end{array}$ \\
\hline Cg01 & $(\mathrm{GAA})_{6}$ & $\begin{array}{l}\text { F: 5'-CTGGGACGTATTTCTGCTG-3' } \\
\text { R: 5'-GCAGCAGCACCTCTCTCTTT-3' }\end{array}$ & $190-198$ & 56 & 11 & 3 & 0.364 & 0.688 & 0.216 & 0.363 & AY729991 \\
\hline $\mathrm{Cg} 06$ & $(\mathrm{CT})_{14}$ & $\begin{array}{l}\text { F: 5'-ACCCTCGCCTCCTTTGTT-3' } \\
\text { R: 5'-TGAGTCGACATGTGTCaGCA-3' }\end{array}$ & $140-162$ & 56 & 12 & 5 & 0.750 & 0.771 & 0.339 & 0.522 & AY729992 \\
\hline Cg11 & $(\mathrm{AG})_{8}$ & $\begin{array}{l}\text { F: 5'-TGAGAGTGAGTTTGTGGGAAGA-3' } \\
\text { R: 5'-TGCTTTTCAGTTGGGACACA-3' }\end{array}$ & $156-160$ & 52 & 11 & 2 & 0.545 & 0.415 & 0.079 & 0.159 & AY729993 \\
\hline Cg16 & $(\mathrm{CT})_{19}$ & $\begin{array}{l}\text { F: 5'-CAAGGCTATTGAGCGTGTGA-3' } \\
\text { R: 5'-TCGAAGGGAGAGAAGCACAT-3' }\end{array}$ & $116-138$ & 52 & 12 & 5 & 0.417 & 0.754 & 0.311 & 0.488 & AY729994 \\
\hline Cg17 & $(\mathrm{AG})_{12}$ & $\begin{array}{l}\text { F: 5'-GATCAAACAACCCACCAACC-3' } \\
\text { R: 5'-CATTGCGGGCTACACAGTTT-3' }\end{array}$ & $106-122$ & 56 & 12 & 6 & 0.750 & 0.840 & 0.438 & 0.616 & AY729995 \\
\hline Mean & & & & & & 4.2 & 0.5651 & 0.6939 & 0.8152 & 0.9496 & \\
\hline
\end{tabular}

polymerase (Invitrogen, Life Technologies) $1.3 \mathrm{U}$. APTC100 MJ Research Thermal Cycler programmed for initial denaturation at $94{ }^{\circ} \mathrm{C}$ for $5 \mathrm{~min}, 35$ cycles at $94{ }^{\circ} \mathrm{C}$ for $1 \mathrm{~min}$, annealing at the primer specific temperature for $1 \mathrm{~min}$ (Table 1), $72^{\circ}$ for $1 \mathrm{~min}$, a final extension at $72^{\circ} \mathrm{C}$ for $5 \mathrm{~min}$. An estimate of microsatellite polymorphism was obtained by screening 12 adult trees from the Tapajos National Forest in the Brazilian Eastern Amazon. We successfully amplified 16 primer pairs, of which five were variable (Table 1). The identification of the alleles was based on the disposition of the fragments in relation to a 10-bp marker ladder on a polyacrylamide gel of high resolution with silver stain.

Data analysis of allelic frequencies was obtained from genotypes of the 12 individuals. Expected heterozygosity, observed heterozygosity, coefficient of fixation, Hardy-Weinberg and linkage disequilibrium were calculatad using GDA (Lewis \& Zaykin 2001) and exclusionary power values were calculated using CERvUs (Marshall et al. 1998).

The mean values for observed heterozygosity and expected heterozygosity were 0.5651 and 0.6939 . The test of pairwise linkage and Hardy-Weinberg disequilibrium showed values higher than the significant value of 0.005 , indicating that these loci are not linked and can be used as independent markers. The combined values (over all loci) for first parent and second parent total exclusionary power were 0.8152 and 0.949 , respectively, with a mean PIC value of 0.613 .

The high levels of polymorphism make the present primers useful for population genetic studies. As part of the Dendrogene Project, we are currently using these markers to investigate questions of mating system, gene flow and paternity in Carapa guianensis.

\section{Acknowledgements}

This publication is a result of the Dendrogene Project: Genetic conservation within managed forests in the Amazon (2000-04 http:// www.cpatu.embrapa.br/dendro/index.htm) executed by Embrapa Amazônia Oriental and their partners in the bilateral cooperation between Brazil and United Kingdom through the Brazilian Cooperation Agency $(\mathrm{ABC})$ and the Department for International Development (DFID). We thank Dominic Cloutier, Milton Kanashiro and Ian Thompson for their valuable comments.

\section{References}

Dayanandan S, Dole J, Bawa J, Kesseli R (1999) Population structure delineated with microsatellite markers in fragmented populations of a tropical tree, Carapa guianensis (Meliaceae). Molecular Ecology, 8, 1585-1592.

Ferreira ME, Grattapaglia D, (1995) Introdução ao uso de marcadores moleculares em análise genética. DF: Embrapa-Cenargen, Brasília

Kanashiro M, Thompson IS, Yared JAG et al. (2002) Improving conservation values of managed forests: The Dendrogene Project in the Brazilian Amazon. Unasylva, Rome, Italy.

Lewis PO, Zaykin D (2001) GENETIC DATA ANALYSIS: Computer Program for the Analysis of Allelic Data, Version 1.0 (d16c). Free program distributed by the authors over the internet from. http:// lewis.eeb.uconn.edu/lewishome/software.html.

Marshall TC, Slate J, Kruuk LEB, Pemberton JM (1998) Statistical confidence for likelihood-based paternity inference in natural populations. Molecular Ecology, 7, 639-655.

Rafalski JA, Morgante M, Powell W, Vogel JM, Tingey SV (1996) Generating and using DNA markers in plants. In: Analysis of Non Mammalian Genomes - a Practical Guide. (eds. Birren B, Lai E) pp. 75-134. Academic Press, New York.

Rozen S, Skaletsky HJ (2000) PRIMER3 on the WWW for general users and for biologist programmers. In: Bioinformatics Methods and Protocols: Methods in Molecular Biology (eds Krawetz S, Misener S), pp. 365-386. Humana Press, Totowa, NJ.

Sambrook J, Fritsch EF, Maniatis T (1989) Molecular Cloning: Laboratory Manual, 2nd edn. CSHL, Cold Spring Harbor, NY. 7. 